\title{
日本におけるプロ野球マイナーリーグの持続的モデル構築に向けて 一野球ビジネスの日米比較から一
}

\author{
石 原 豊 一*
}

\section{A Sustainable Business Model of Minor League Baseball in Japan Based on a Comparison of the US and Japanese Baseball Businesses ${ }^{\dagger}$}

\author{
Toyokazu ISHIHARA*
}

\begin{abstract}
Independent baseball leagues were established in Japan after the decline of the industrial league because of the recession in the 1990's and confusion about the reorganization of the Nippon Professional Baseball (NPB) in 2004. Though four leagues have been inaugurated up to now, their management situation is not strong and several teams face a crisis situation.

This paper discusses a future view of community-based small sports businesses and a strategy for sustenance through comparison of minor league business in Japan and North America, based on fieldwork carried out in 2009 from a perspective that considered independent baseball leagues that have attracted attention in recent years and farm leagues of the Nippon Professional Baseball (NPB) as "Minor Leagues".

This paper introduces the marketing strategies of MLB utilizing farm teams, and the management of $3 \mathrm{~A}$ class minor league baseball teams linked to the activation strategy of the franchise city and current states of minor league business differentiated from major league business as an amusement commodity. Furthermore, problems about independent leagues in Japan not yet established as sport businesses are presented.

For the development of minor league business in Japan in the future, it will be necessary to evaluate the commercial value of the NPB's farm team and improve cooperation with independent leagues as the talent reservoir.

Considering the decline of corporate sports, the reduction of participants due to falling birthrate, the decrease in popularity of baseball and the subsidy reduction to Olympic sports by journalizing of national projects, the environments surrounding sports in Japan at present are becoming more severe. Though it seems that the role of minor leagues as starting points for the local activation of sports and as receivers of athletes after graduation as well as player supply sources for the top leagues will grow in the future, in these situations a clear view of the future cannot be drawn yet.
\end{abstract}

Key words : Independent Baseball League, Minor League, Community-based Sports, Sport Business

\footnotetext{
”原稿受付 2010 年 9 月 2 日 原稿受諾 2010 年 12 月 13 日

*立命館大学大学院 $=$ 603-8577 京都府京都市北区等持院北町 56-1

* Graduate School of Ritsumeikan University, 56-1, Tojiin-Kitamachi, Kita-ku, Kyoto, Kyoto, Japan (603-8577)
} 


\section{1.はじめに}

2010 年 7 月初め, 前年発足した独立プロ野 球リーグ・関西独立リーグが翌年に向けての NPO 法人化の方針を発表した. 2010 年後期シー ズンは公式戦を引き続き行うものの, 選手へ の報酬の支払いは前期終了の 6 月をもって打ち 切った上, リーグ, 球団は選手に対して野球を する環境の夕を提供し, 選手は個々でアルバイ トなどにより生活費を稼ぐことになった。 日本 初の女子プロ野球選手の獲得などで話題を集 め, 初年度の京セラドーム大阪での開幕戦では 11,592 人の前で上々のスタートをきった日本第 3 のプロ野球独立リーグだったが，シーズンの 途中にリーグ運営会社が各球団に分配金を支払 うことなく撤退し, 以後, 各球団が出資した新 会社による事実上の自主運営という形で何とか シーズンを乗り切るなど, 不安定な経営を露呈 し, 1 シーズン半で新たな地域スポーツのかた ちを模索することになった.

1990 年代の不況のもとでの社会人野球にお ける企業チームの撤退や 2004 年のプロ野球界 での再編騒動を受けて発足した我が国の独立プ ロ野球リーグだが，これまで４リーグが立ち上 げられたものの, いずれのリーグ, チームとも 黒字を達成したことがなく（注 1), 数球団は その存続の危機にさらされている.

他のスポーツにおいても，グローバル経済の 進展の中, 国際競争力を求められるようになつ た企業が, 合理化の名の下, 運動部を休止し, 地域密着型のスポーツクラブへの転換を余儀な くされている例が目立つようになっている. 地 域密着型のスポーツビジネスとして, 近年注目 を集めている独立系プロスポーツリーグである が ${ }^{1)}$, この新興のプロスポーツビジネスは今後 ぞうなっていくのか, また, それが存在し続け ていくにはなにが必要であるのか. 本稿では, 2009 年 8 月に実施したフィールドワークをも とに, 野球ビジネスの先進国米国との比較を通 して, 日本プロ野球 (NPB) の二軍を含めたトッ プリーグに対する下位プロリーグをマイナー
リーグと捉える視点から，わが国における小規 模スポーツビジネスの現状とその問題点につい て述べていく.

\section{2. アメリカのマイナーリーグ・ビジネスの最 前線：3A コロンバス球団の事例から}

\section{1 マーケティング戦略上のマイナーリーグ}

コロンバス（Columbus）は，都市域人口 150 万を越えるオハイオ州の州都である。ここに本 拠地を置くマイナーリーグ球団がクリッパーズ である. 長らく MLB (MLB) の名門ニューヨー ク・ヤンキースと選手育成契約を結び, マイナー リーグの最高ランクに位置づけられる $3 \mathrm{~A} ク ラ$ スのファームチームとして活動していたこの球 団は, 2009 年シーズンの新球場への移転と同 時に新たにクリーブランド・インディアンスと 選手育成契約を結んだ(注 2)。この背景には, MLB 球団のファームチームを利用したマーケ ティング戦略が存在する.

北米マイナーリーグは元々, MLB とは別個 に誕生し, 独自に展開されていた。1920 年代 にセントルイス・カージナルスのゼネラル・ マネージャー, ブランチ・リッキー（Branch Rickey）が，若手選手養成機関としてマイナー リーグの球団を買収し, 自軍の傘下に置くよ うになってから，トップチームが契約した選 手を派遣して試合経験を積ませる「ファーム」 として機能するようになった. その後, 他球団 もこれに追随し，1950 年代終わりまでには, クラス別にランク付けされたマイナーリーグ球 団が, MLB の親球団から選手の供給を受ける という現在の形が完成した.この結果, MLB 球団は北米各地に散らばるマイナーリーグの ファームチームに選手を送り込んで, 適宜その 入れ替えを行うことになった。

この制度の最大の難点は, ファームチームと トップチームのフランチャイズ間の選手の移動 にある．特に二軍に当たる $3 \mathrm{~A}$ 級のチームは, メジャーチームの余剩戦力の貯水池としての役 割も担っており, トップチームとの選手の入れ 替えは盛んに行われる，そのことを考えると， 
このクラスのファームチームは親球団の本拠地 近くにあった方が良い。実際，シアトル・マリ ナーズは, 3A チームを長らく隣町のタコマに 置いているが，これにより補欠選手のコンディ ションの見極めもしやすくなるし，選手の入れ 替えも円滑に行える. また, 故障したメジャー リーガーのリハビリの場としても $3 \mathrm{~A}$ チームを 利用しやすくなる.

そのことを考えると, 親球団の本拠地から比 較的近いコロンバスはインディアンスにとって 3A チームの配置として適当である. 加えて, マーケティングの観点からもコロンバスはク リーブランドにとって理想的である.

MLB 球団のいくつかは, 現在ファームチー ムを親球団のマーケティング戦略上に位置づ けている（注 3). 地元マイナーチームの選手 がMLB に昇格すれば，その選手目当てにファ ンは親球団のスタジアムにも足を運ぶことにな るし, 逆に親球団のファンが近隣のファーム 球団の試合を観戦するケースも生まれる。 イ ンディアンスの場合, 3A のコロンバス, 2A の アクロン (Akron), A 級のレイクカウンティ

(Lake County), マホニングバレー（Mahoning Valley）のマイナー 4 球団がクリーブランドか ら 200 キロ以内に本拠を置いている. 車社会の アメリカではこの距離は日帰りで観戦に行ける 範囲である.ここからは, 現在 MLB では, ファー ムチームを, チーム強化はもちろん顧客獲得の ためのツールとしていかに活用するかを戦略的 に考えながら利用していることが窥える.

\section{2 ボールパークのリノベーション}

北米においては, 1980 年代後半以降マイナー リーグの人気が回復するとともに, 荒廃したダ ウンタウンの再開発と地域経済活性化のツール として, 地方自治体がプロスポーツチームを 利用する潮流が見られるようになってきた2). 100 万を越える都市域人口を背景にマイナー リーグ随一の観客動員を誇つていたコロンバス 球団も（注 4 ）, 2009 年郊外から市中心部にホー ム球場を移転した。「マイナーリーグ No.1」と
球団が胸を張る最新鋭のコロンバスのスタジア ムは, 収容人数が少ないこと以外は NPB の本 拠地球場と同等の設備を備えている. 本項で は，マイナーリーグのスタジアムが，地域活性 化のツールとして機能すべくどのような工夫を 凝らして建造されているのかを，コロンバス の新球場「ハンチントン・パーク (Hantington Park)」から検証する.

現在, 北米の新球場の多くが掘り込み式の フィールドを採用している. グランドレベルか ら地面を掘り込んでフィールドを造るのだが, こうすることにより観客は入場後, 階段を下っ て席に着くことになり, 観戦の妨げになるス夕 ンド上の出入り口を設置せずにすむ上，建設費 も安くつく.さらに観客は, スタンドからフィー ルドの先にあるダウンタウンの摩天楼を眺める ことになり，町の風景を借景として利用でき る. 年 1 回の花火大会ではこのスタンドは市民 に開放されるのだが，球団はこのイベントを通 して野球に興味のなかった市民を新たな顧客と して呼び込もうと目論んでいる。

入場料収入は, 球団経営の柱のひとつである が，現在の北米のプロ野球，特にMLBにおい ては富裕層からの高額チケット収入にその重点 が置かれている4).コロンバスにおいても，下 層の一般スタンド上の上層スタンドに設置され た特別席の年間契約によって，法人，富裕層 から多額の収入を得ている.フィールドを取 り囲む形で建設された球場敷地内のビルのう ち, 内野フィールドを囲む部分の 2 階にある 計 27 室のラグジュアリー・ボックスは室内で パーティーをしながら，野球を見たいときに室 外のシートでいつでも観戦できるようになって いる.このスペースは日本円にして 1 部屋年間 400 万円で売り出されていたが, 2009 年はシー ズン前に完売した（注 5 ）。加えて試合ごとの ケータリングは別料金だから, 年間 1 億円以上 の金額を固定客から得ることになる.

球場内のビルはライト側にも伸びていて, 外 野寄りの上層スタンドはオープンエアのパー ティースペースになっている。こちらは試合毎 
の切り売りとなっており, 地元民の社交場と なっていた．このスペースは，試合のない日や 時間帯も会議場などとして貸し出されている. 球場は市から球団へ低料金で貸し出されている のだが，様々なかたちで市民に利用させること で, 公共性を保ち, 球団は, 野球興行以外での 収入を確保している. スタンドでのパーティー の参加者は, ライトフェンス上のバーカウン ターに座って観戦できる. 都心の再開発という 制約の中建設したこの新球場は, ホームプレー トからライトポールへの距離を十分にとれず, そのため右翼フェンスは非常に高いものになっ ている. 従って 1 階部分には観客席はなく, 2 階部分だけを観戦スペースとしている。緑色 の高いフェンスはボストンのフェンウェイパー クの名物である高い左翼フェンスである「グ リーンモンスター」を意識して設置され，ネオ クラシック型球場に彩りを添えている. フェン スの裏には街路が通つているが，ここにも敷地 外から試合を立ち見できるサンフランシスコの PNCパークの外野フェンスを模した格子空が 2 ヶ所しつらえられ，ここからフィールドを覘 けるようになっている。実際，ここに簡易椅子 を置いて観戦していた家族連れがいた。 彼らは 普段スタンドで観戦するのだが，この場所から 一度試合を観てみたいと思いこの場所に陣取つ たという. 球団はこの逆のケース, つまりここ から試合風景を覘いた市民がその雾囲気に魅力 を感じてチケットを購入することを目論んでい る. また試合のない日には, 可動式のバックス クリーンを下ろすことによって, 通りから球場 内を望めるようにし, 球団は常日頃から道行く 人に球場の中を見せることにより, それまで野 球に興味のなかった人々を新たな顧客として獲 得しようとしている. また, センター周辺の外 野席は芝生席となっており, 子供連れが夕涼み を楽しめるようになっている. この光景も入場 せずとも通りから見ることができ，この球場の 魅力を市民に知らしめている。

レフト後方の 4 階建てのビルはグッズショッ プとバーになっており，入場料をチャージ代わ
りに老若男女がアフターファイブを楽しんでい た.このビルの屋上には，シカゴのリグレー フィールドの外野後方の私設スタンドを模した 観客席があり, 高いフェンスや格子空と同様の 「どこかでタたような」(注 6 ) 演出は, ファ ンをひきつける要素となつている.

1 万席を擁するこの球場には, 1 試合平均 9,252 人が集まる（注 7 ）。座席定員を超える入 場者を記録することもあるが，この状況になつ ても，この球団ではソールドアウトという言葉 は使わず， ‘at capacity’ と表現する。 チケット は売り切れることはない. スタンドの後方の通 路や，レフトスタンド上のバーなど客を収容す るスペースはいくらでもあり，1 万 5,000 人が 公称の収容人数になっている3 .

このように巨大な集客装置となったこのボー ルパークは, 地元企業にとって格好の広告ス ペースになる. 球場の名は, 球団のメインバン クがスポンサーとなって命名権を買い取ってい る。場内の至る所には広告が入り，これもまた 球団に大きな利益をもたらす。右中間にあるス コアボードは, 地元新聞社がその広告権を買い 取り, 外野ポールにまでガス会社の名前が入つ ている. スコアボードの後方にそびえるビル は，スポンサーとなつた新聞社のビルで，内野 スタンドから見るとスコアボードの広告と共に 目に入るように設計されている。このように内 野スタンドから望む借景までもが, 球場内の広 告とコラボレートし， 2 重の宣伝効果をもたら している.

また, レフト側の入り口を入ってすぐ左手の 壁には, この町に存在した歴代の野球場とそこ でプレーしたプロチームの歴史が描かれてい た. 北米では, その町に存在したチームや選手, スタジアムの歴史を非常に重要視する。 その伝 統は，その町にプロチームが存在する必然性を 創り出している.

選手たちが使用する施設に目を移すと，ス夕 ンド下のクラブハウスも最新鋭のものである. 広々としたロッカーに囲まれたソファースペー スの隣には，早出してくる選手たちが，練習の 
合間にもリラックスできるようにと，ジェット バス浴槽だけでなく, 卓球台やキッチンまで備 えてある、ロッカールームを出ると, バッティ ング練習場もあり, 試合中も選手たちは, ここ でティーを吒いて出番に備える.

旧球場の周囲は墓地などがある閑散とした地 域で, 治安も良いとはいえなかった。 かつて北 米のスタジアムはモータリゼーションの発展と ともに，駐車場の確保の容易な郊外に移転した が5)，集客装置を失つた都心部は，治安の悪化 を招いた。近年では，MLB においても都心部 の活性化を狙った再開発と連動した野球専用球 場の新築が盛んであるが, 1990 年代から本格 化したこの動きは, マイナーリーグにも及び2), ここコロンバスにおいても実行された。

市中心のビジネス街に隣接して, 特に仕事の 後に市民の集まる場所として市当局は, 飲食店 街とアイスホッケー・アリーナを建設した。こ のことは市民に社交場を提供することになった が，夏季に夜を楽しめるイベントがないことは 大きな課題であった。 そこで，アリーナに隣接 する区画に新球場を建設することで，この一角 を，年を通じての集客装置とすることを目論ん だのである. MLB とまではいかないものの, 連日 1 万人近い集客をしてくれるクリッパーズ は, 町の活性化に貢献している. ナイター観戦 を終えたファンは少なからず, 隣接する飲食店 街に繰り出し, ここで落としたカネは税として 市に還元される.

クリッパーズは，市民に娛楽を提供し，野球 というエンタテイメントを消費した観客は，地 元経済に貢献, 球場とその周辺環境を整備した 行政側もまた税の徵収を見込むことができる. このように，マイナーリーグというコンテンツ を通じて地域には正の循環が起こっている。 ロンバス球団の筆頭オーナーは, 地元カウン ティである. 行政がプロスポーツを持つ必然性 がここにある.

\section{3.「メジャー」と「マイナー」の商品として の分化}

これまで述べたようなマイナーリーグの地域 コミュニティ活性化のツールとしての役割を 日本のNPB の二軍や独立リーグに求めること は，両者がいまだ集客装置としてのスポーツビ ジネスとして確立していない現状を考えると， 現在のところ難しい。 日本においては，地域経 済に影響を及ぼすようなスポーツビジネスは NPB の一軍やサッカーの J リーグなどにいま だ限られている。本章では, 北米においてマイ ナーリーグ・ビジネスが活況を呈している素地 として, MLB との娛楽商品としての分化が存 在していることを指摘する.

2009 年 9 月上旬, 新潟県知事が将来の NPB 球団誘致の可能性をマスコミに向けて発表し $た^{6}$ ）。の年開場した新球場というハードを恒 久的に満たす集客コンテンツを求めての動きと 思われる. 全国ネットのテレビ放映が減少し, 放映権によるビジネスモデルが崩れ始めた上, パ・リーグを中心に地方球団が成功を収めてい る現状において，空白地帯であった日本海側 にNPB が進出することはありえない話ではな い. 実際，2010 年 10 月の横浜球団売却を巡る 騒動の際には, 新潟への移転話も持ち上がつた.

しかし, 将来的にNPB の球団が四国や北信 越に移転・拡大すると, これまで地方にプロ野 球を根付かせる地道な努力をしてきた独立リー グは，おそらくたちまちのうちに危機にさらさ れることになる。一方，北米においては，同じ 都市圈に MLB とマイナーリーグ球団が共存す ることは珍しくない。このことは，娛楽商品と しての両者がもはや競合するものではなくなつ ていることを示唆する.

北米においては，その事業規模，選手獲得網 をグローバル規模に拡大したトップリーグは, 巨大ビジネス化し，一般の家族の娛楽としての 役割を果たさなくなってきている。 この流れの 中，庶民の娛楽ビジネスとしてのマイナーリー グは, 1990 年代以降急成長している4). 
1990 年代の半ばまでは, どの MLB の球場も 一番安い席は 5,6ドルほどで入場できた. とこ ろが, この 20 年の MLB のグローバルな事業 展開は単に選手獲得網に留まらずそのマーケッ トも地球規模のものにした7)。 その結果, 巨大 ビジネスと化した MLB は贅沢な娛楽となつ た. ニューヨーク・メッツの新球場, シティ フィールドの 2009 年シーズンにおけるポール 際の内野下段席の価格は 90 ドルだった. 現在 において 10 ドル以下で観戦できる席は, 人気 球団の球場では皆無に近い. おまけに, 敷地内 にメリーゴーランドや観覧車まで備え付け, テーマパークと化した MLBの球場には, 飲食 物は一切持ち込めず，開場から試合終了まで ファンはひたすら消費を強いられる 戦は現在，多くの人々にとって日常の娛楽では なく, 家族を連れての年数回の一大消費イベン トとなっている。 この高額娛楽商品と化した MLB 観戦に対し, 家族連れが毎週末に気軽に 楽しむ日常の手軽な娛楽としての役割を果たし ているのがマイナーリーグである.

シカゴ郊外にジェニーバ（Geneva）という町 がある. 日曜の午前中, 駅からは MLB チーム のジャージをまとつた多くのファンが近郊列車 に乗り込む. その一方で, 町外れにある球場に も多くのファンが詰め掛ける（注 8). 7,000人 収容のこの球場の 2008 年シーズン 1 番の大入 りは 1 万 4,872 人だった. 収容人員を大きく上 回るファンを詰め込める秘密は, グループ専用 のパーティー席のある外野スタンドとその後方 に広がるピクニックエリアである。一面芝生の この広場ではフィールドで行われているゲーム そっちのけで子供達が戯れている.

この球場を訪れるファンの観戦理由は $2 つ に$ 大別される、第一は, 家族が気軽に楽しめる空 間であることである. 駐車場が隣接する規模の 小さい地元球場だとアクセスしやすいし, 子供 を安心して遊ばせておくことができる．第二 は MLB では体験できない選手とのふれあいで ある、「将来のスター」から気軽にサインを貪 えるマイナーリーグのファンは, 開場とともに
スタンドに陣取り, サインペンとベースボール カードを手に選手に声をかけている，選手がペ ンを走らせるカードは, 球団に多くの収益をも たらしている.

MLB 球団とマイナーリーグ球団の共存はこ こだけの話ではない。カカンザスシティはカンザ ス州とミズーリ州の境にまたがって位置する町 である. MLB 球団のロイヤルズのスタジアム はミズーリ州側の郊外に位置しているが, 州境 を挟んで反対側のカンザス州側には 2003 年か ら独立系ノーザンリーグのチーム， T ボーンズ が本拠を置いている．移転と同時に建造された 新球場は, 2008 年からプロサッカーのホーム も兼ねることになり，レフト側に新たにスタン ドが設置された. ダウンタウンからバスで 40 分という場所にありながらも，球場の周囲には モーターレース場やショッピングセンター, レ ストラン街が林立している。一大集客装置の一 部として T ボーンズは, 地元コミュニティに 大きく貢献している.

先述のコロンバスの例もあわせて考えると, 今やマイナーリーグは北米では地方都市活性化 の重要なコンテンツになっていると言える. 現 在において, マイナーリーグは, 贅沢なレジャー としてのMLB とは全く別の日常の娛楽商品と しての活路を見出している.

ニューヨークに本拠を置くヤンキースとメッ ツは, 2000 年から各々, A 級のファームチー ムを市郊外のスタテンアイランドとブルックリ ンに移転させた。これらの MLB 都市郊外のマ イナーチームは, ファンの野球観戦を日常化さ せ, MLB 観戦の予備軍としての顧客をも育成 する役割を果たしている. 北米の野球は, メ ジャー, マイナーという別の娛楽コンテンツを 気分や時期に応じて使いわけている. 無論前者 は贅沢な, 後者は日常のエンタテイメントなの であるが, その使い分けが成立する土壌には, 野球観戦が日常の習慣として定着しているとい う米国における「ナショナル・パスタイム」の 浸透度が存在している。 


\section{4. 危機にある日本の独立リーグ : 四国九州ア イランドリーグ・長崎セインツの事例から}

前章で北米のマイナーリーグが，今や MLB との商品としての差別化に成功し, 地域に根ざ した集客装置として地域コミュニティ活性化の 重要なコンテンツになっている現状を紹介した が，本章ではわが国の独立リーグの例からマイ ナーリーグ・ビジネスが地域活性化という理想 とその有効なコンテンツにいまだなりえていな い現実との狭間に立たされている現状を提示す る.

かつて海軍と造船の町として栄えた長崎県佐 世保市は，テーマパーク，ハウステンボスの破 綻に象徴されるように他の地方都市と同じく再 活性化という大きな課題を抱えている.

この町に本拠を置く独立野球リーグの球団 が, 長崎セインツであった。当初, 地元実業家 によって九州での新リーグ結成が計画された が，小規模とはいえチーム運営費に加えて選手 に報酬を出さねばならないプロチームを, 不況 の中運営したいという経営者は多くは現れな かった. 結局, マーケティング拡大のため対戦 カード数を増やそうする四国アイランドリーグ

(現四国九州アイランドリーグ，IL）の拡大戦 略の一環として ${ }^{910)}$, 長崎セインツが誕生した。

「子供たちがスポーツに触れてすくすく育つ 環境をつくる」(注 9 ) というコンセプトの下, 長崎球団はプロ球団としての活動を始めたが, 採算ラインである 1 試合平均観客動員 1,400 人 を集客することができず, 初年度から経営危機 に陥つた. 2009 年シーズンは前期優勝を果た し, 観客動員は改善されたものの, 平均 630 人 という状態では, 財政事情は好転しなかった. 球団存亡の際にファンからの募金によりチー ムを存続させた NPB 広島カープの古事になら い，浄財を呼びかけたが，100万円ほどの募金 では，3,000万円超の負債を抱えた球団の財政 事情を好転させることはできなかった。

野球そのものに特段の縁があったわけでもな い長崎球団のオーナーが, 独立野球リーグ経営
に乗り出したきっかけは, 北米の独立リーグに 触れたことであった。佐世保市の姉妹都市であ るセントポール市から独立リーグの強豪, セイ ンツを呼び寄せる企画が持ち上がり，その実行 役として打診を受けたオーナーは，セントポー ルで試合を実見し，衰退する地方の活性化のコ ンテンツとして小規模のプロスポーツに可能性 を見出した. 彼は私費 1,500 万円を投じてセン トポール球団の日本遠征を実行に移し，九州各 地のクラブチームとの対戦に加えて, IL 徳島 球団との日米独立リーグチーム同士の対戦も実 現させた。これをきつかけに，地元佐世保にプ ロチームを設立する構想が持ち上がり, 長崎セ インツが誕生した。 しかし, 地域活性化のコン テンツを目指して設立された独立プロ野球チー ムも一事業家の資金力だけでは維持は難しかつ た (注 10).

この地域密着型のプロ球団に対する県民の関 心は低かった。市中のところどころに見られる ポスターも市民の関心を引くまでには至ってい ない状況では, チームのボランティアスタッフ でさえ, 普段の生活の中でセインツの情報を得 ることは難しいと言つていた（注11）。試合情 報などの広報は, 長崎球団だけでなく独立リー グ系スポーツチームにとっての大きな課題であ る. 球団やリーグのホームページを見れば試合 スケジュールなどはわかるのだが，現実には全 ての人がインターネットにアクセスできるわけ ではない.

地域密着型のプロサッカーチームとしてア ルビレックス新潟を立ち上げた経験を持つ, 日本第 2 の独立プロ野球リーグである BCリー グ（BCL）の代表は，独立リーグのビジネスモ デルは完成に向かいつつあると主張する，BCL は, 地域密着の活動を地道に続けた結果, 固定 ファンの創出に成功し，地元企業の支援を将来 的にも受けることが可能になり, 資本が枯渴し た場合でも増資を行うめどは立ったと言う（注 12)。地方にスポーツ観戦という娛楽を提供 し, 企業スポーツの衰退によって行き場を失つ たアスリートを活用したスポーツ文化の浸透と 
青少年の育成という役割を果たすマイナーリー グとしての独立リーグは, スポーツコンテンツ としての地位を確立しつつある.

しかし，景気低迷が叫ばれる中，外部からの 資金注入に頼るビジネスモデルは極めて不安定 と言わざるを得ない. 実際, 地域密着型の独立 系スポーツビジネスの成功例とされるバスケッ トボールの bj リーグにも，スポンサー企業の 破綻により, 経営危機が叫ばれている球団が出 ている ${ }^{11)}$. 地域密着型の持続的なビジネスモデ ルは構築されつつあるとはいえ, 独立野球リー グ, 球団の経営危機は度々報道されている.

ILにおいても, 九州への拡大によって誕生 した福岡, 長崎の両球団は, NPBの人気球団 ソフトバンクの存在もあって衆目を集めるには 至らず，福岡は 2009 年限りで活動を休止し, 長崎は 2010 年のシーズン終了をもって解散し た. 北米の MLB とマイナーリーグの商品とし ての分化のような状況は, 日本においては, 未 だ確立していないことがここからも窺える.

2009 年シーズンの独立プロ野球 3 リーグの 1 試合あたりの平均観客動員数は 933 人であっ た. 最多のBCLでさえ 1,295 人である. 観客 数が伸びねば, 各チームの広告収入も伸びてこ ない. ビジネスモデルが確立しつつあるという 自信とはうらはらに, 独立リーグ各チームの置 かれている現実は厳しい。

\section{5. 独立リーグの魅カ：プロのプレーか育成か}

長崎セインツの不人気の理由のひとつにサッ カーチームとの違いを挙げることができる. セ インツの観客の多くもこの点を指摘する（注 13). 地域密着型のプロスポーツとして創設以 来着実にチーム数を増やしている Jリーグを頂 点とするサッカーは, どのチームでも条件さえ 満たせば，プロ化し，成績次第でトップリーグ に昇格できる. 長崎には, Jリーグを目指すサッ カーチームとして V ファーレンがある. 現在 アマチュアのトップリーグ JFL に加盟してい るこの球団には, Jリーグへの昇格という夢が ある.さらにファンは, クラブワールドカップ
での優勝という「世界一」の夢までも見ること ができる。 それに対し，セインツでは選手個々 がNPB に入団することはあっても，チームが NPB に昇格することは制度上ない，現状にお いて, プロ野球独立リーグが, 自らを魅力ある ものにするには, NPB のスター選手を輩出す ることが必要である。無名選手しかいない状況 では，いくら地域密着を掲げたところで, 観客 を呼ぶことは難しい.

スター不在のリーグを魅力あるものにするた めに元 NPB のベテラン選手を参加させるのも ひとつの方法ではある。実際, プロらしい卓越 したプレーは, 独立野球リーグの観客において も観戦誘因第 1 位を占めるという研究結果も出 ている ${ }^{12)}$.

IL は発足当初, 既存のアマチュア野球組織 からあぶれた若い選手の NPBへの登竜門とい う自らの位置付けから，NPB 経験者を受け入 れなかったが，近年ではNPB だけでなく外国 のプロ野球経験者を国籍に関わらず入団させて いる，彼らが，アマチュア経験しかない選手に とってのよき目標にもなることは想像に難くな い. 北米マイナーリーグをはじめ, プロ選手 として 5 カ国でプレ一経験のある選手も, 経験 豊富なべテラン選手と一緒にプレーすることに よる若手選手への正の刺激を指摘していた（注 14).

2009 年シーズンの短期間 IL 高知に在籍した 元メジャーリーガー, 伊良部秀輝が登板した試 合の盛況振りをみれば，かつてのスター選手が 観客動員に大きく貢献することは間違いない.

北米独立リーグでは, MLB のロースターにも れたベテランの参加は日常茶飯事で, 2009 年 にはカナダに本拠を置くケベック・キャビタル ズ（カンナムリーグ）にかつてのスター選手エ リック・ガニエが入団し, シーズンを過ごした。

北米の独立リーグでは，若手選手の育成とべ テランによる集客, プレーレベルの向上の両立 を図るため, 選手たちのキャリアを数段階に分 け，ロースターにおける各段階の選手の人数制 限を設けている，各選手の報酬は，このキャリ 
アによるランクによって決まり, このことは自 動的にチーム毎の総人件費を均等にし，同時に 戦力の均衡にも役立っている.

しかし，日本の独立リーグのファンの多く が，その魅力を語るときに挙げるのが，技術的 に未熟でも, ひたむきな若い選手の姿である (注 15). 集客の目玉として何を前面に出して行く ベきなのか, このことも日本の独立リーグが抱 えている大きな問題である.

\section{6. トップリーグとの関係の日米比較}

日米の独立リーグを共に経験したベテラン選 手は，両者を比較して決定的に違うのは，トッ プリーグとの関係であると言う（注16）.

現在 NPB でのプレー経験のない国内選手の $\mathrm{NPB}$ への入団は, 秋のドラフトでの指名が条 件となっている. 北米においてもこの条件は同 じであるが，プロ経験のある選手が MLB 球団 と契約するのは年を通して可能である. 実際, 独立リーグの選手がシーズン途中に MLB 球団 と契約する選手は少なくない４月に独立リー グでプレーしていた選手が，10月にワールド シリーズの舞台に立つことも十分にありうる.

彼の持論は, NPB 球団との育成契約はドラ フトでの指名なしでも年を通じて結べるように すべきであるというものである. そうなれば, 前年の秋のドラフトに洩れた選手でも, 活躍次 第で NPB に入団できることになる. その上, 本契約の期限である 7 月末までに結果を残せば 一軍の舞台に立つことも可能になる. その結 果, 選手の流れが活発化すれば, 独立リーグ がNPBへの登竜門としての機能をより強化で きるので, 選手にとつてもより魅力が増し, そ の報酬の低さを覚悟の上でもチャレンジするレ ベルの高い選手も増えてくるという展望も開け る.

そうなれば，短期トーナメントで力を発揮で きなかったトップアマチュア選手の再チャレン ジの場としての機能を独立リーグは持つように なるし, NPB のスカウトも長いシーズンでコ ンスタントに力量を発揮せねばならないプロと
しての適性を見る機会を確保できる.

野球において, アマチュア選手とプロ選手と 最大の違いは，ある一定時期にピークを合わせ るアマに対して, プロは短くても 2 ケ月, トッ プリーグならば半年に渡って一定レベルのコン ディションを保ちながら競技しなければならな いところにある，そのプロとしての本当の力量 を見る場として, 独立リーグは大きな可能性を 持つ. NPB にとっても，プロの連戦に耐えう るかどうか疑問のある選手のドラフト指名は見 送って，独立リーグでのプレーを見てから育成 選手として採用, 戦力となりそうなら本契約で きるようにすれば，無駄な投資を避けることが できる，希望しない球団から指名された選手の 迂回路として利用される可能性は残るものの, 入団を拒否したドラフト指名選手については, 次のドラフトまで待たせればよい。 そうして, アマチュア選手にとつて独立リーグがより魅力 が増せば，選手の流動性も高まり独立リーグそ のものの競技レベルの向上にもつながる.

一方で, 日米でプロ経験のあるベテラン選手 たちは，口をそろえて独立リーグに身を投じる 若者達の野球に対する意識の甘さを指摘する

(注17)。プロである以上，独立リーグは選別 の場であり，その結果一定のレベルの選手だけ が生き残ることができるシステムを構築すべき である，その部分を克服する上でも，NPB と 独立リーグ間の選手の移動, アマチュア球界と 両者との選手の移動の促進化は欠かせない.

NPB や北米，あるいはアジアのプロ野球から 洩れてしまったベテランにとっても再挑戦の場 として独立リーグが機能すれば，選手にとって も，ファンにとってもより独立リーグの魅力は 増す。また, 野球のグローバル化において野球 途上国のトップ選手の最初のステップとして日 本の独立リーグがその受け皿として機能すれ ば，MLB を頂点とする世界のプロ野球におけ る選手の流れが, 日本に向くことも考えられる. 


\section{7. ビジネスコンテンツとして機能していない NPB のファーム}

MLB への人材供給地と化しつつあるNPB が 今後, 世界の野球界において MLB と並ぶ核と なろうとするならば，世界中から日本に選手が 流れてくる道筋を作る必要がある.

2010 年シーズン, 独立プロ野球の BCLから 2 人のベネズエラ人選手が NPB に移籍した. うち一人は 2009 年 IL でプレーし，ここで好成 績を残すと NPBへの移籍を射程において, 関 東地方に拠点を置く BCL 群馬球団に移籍し, シーズン途中にオリックス球団に移籍すると, 一軍の戦力として十分な働きをした。この移籍 にはオリックスから BCL へ移籍金が支払われ たという.

このようにNPB が独立リーグと提携し，プ 口の底辺の浅い，あるいはプロのない国からの 有望選手が独立リーグに流れる道筋をつくれ ば，マーケットも広がる，運動能力は高いが実 戦経験の乏しい外国人選手の育成に独立リーグ を利用する方法もある。実際, 日本の独立リー グに, 北米の代理人から選手の売込みがあった り（注 18）, NPB の広島球団がドミニカ共和国 で運営する野球アカデミーの選手を IL に送り 込んだりと NPB や北米野球が選手の育成の場 として日本の独立リーグを利用する動きも出始 めている. それらを考えると, NPB は独立リー グに対して支援していいはずだが，現状におい てはその動きは鈍い.それどころか, 自チーム のファームですらビジネスとして有効利用して いない.

オリックス球団は 2000 年から 9 年間, 二軍 を「サーパス神戸（2006 年からはサーパス）」 として, 大手工務店から命名権料を取り, 別チー ムとして運営, 球場も神戸市郊外の市営球場を 専用球場として借りてホームグランドとしてい た.ここでは, 大人 300 円の入場料をとつてい たが，観客動員は芳しくなかった，一方で，同 じ関西の人気球団である阪神は二軍の公式戦を ファンサービスと捉え, 練習グランドである鳴
尾浜球場で無料開放している. 500 人程しか座 れないスタンドは平日でも席を探すのに苦労す るほどである.しかし, 人気球団のこの姿勢は, 二軍戦は無料で観戦するものという固定観念を ファンに植え付け，マイナーリーグがビジネス として成立する素地を球界が自ら摘み取ってい るようなものである.

西武球団も, 2005 年から 3 年間は, 二軍の 命名権を販売していたが，2007 年，命名権の 売却先企業の違法行為が問題化すると, その 後, 二軍のチーム名を一軍と同じものに戻して いる。 また，本拠地を横須賀に移し，地域密着 型のチーム，「横須賀シーレックス」として二 軍を運営していた横浜球団も, 経費節減の観点 から 2010 年シーズン終了をもって一, 二軍の チーム名の分離をやめた.

以上のような状況は，日本においては，いま だNPB の二軍をマイナーリーグとして収益を 生夕出す動きは確立されていないことを示して いる.

\section{8.おわりに}

関西独立リーグは, シーズン終了後, 2011 年シーズンの概要を発表した。神戸球団は, 親 会社が経営から撤退し, 一旦解散の上, 本拠地 球場のある兵庫県三田市に拠点を置く NPO が 運営する新球団に引き継がれることになった。 他の 3 球団は存続の上, 新たに大阪府に本拠を 置く球団の参加が決定し, もう 1 チームの参加 を募集して，6 球団でのリーグ戦を目指すこと になった．各チームは加盟料を支払つてリーグ 戦に参加し，リーグ組織はリーグ戦にかかる費 用一切を負担することになった。選手の給与は 原則なしで, 試合興行で利益が出たときのみ報 酬を支払うことになった。

発足以来の経営難を考えると, 時に有名選手 も出場する人気チームの二軍戦が無料という関 西にあって, 無名の選手しかいない独立リーグ が 1,000 円の入場料を支払つて観るコンテンツ として成立する見込みは果たしてあったのだろ うかという疑問が残る。1 試合 2,000 人という 
発足前の観客動員の予測の根拠がどういうもの であったのかは，今となっては知る術はない が，このリーグはその発足時の事業見込みから 甘すぎたと言わざるをえない.

本稿では, 米国プロ野球の現状との比較か ら, 日本のNPB の二軍や独立リーグが今後マ イナーリーグとして持続的なプロスポーツとし て存続していく道を探ってみた.

現状において，日本においては両者を同じカ テゴリーにはめ込むことは難しいかもしれな い. ビジネスコンテンツとしての役割とトップ リーグへの人材供給源としての役割を両立して いる北米の MLB のファームと独立リーグとは 違い, 日本においてはNPB の二軍は前者のみ, 独立リーグは後者のみの機能しか果たしていな いのが現状である。しかし, 企業スポーツの衰 退, 叫ばれる野球人気の低下, 少子化による底 辺の縮小による将来的なトップリーグ NPBへ の選手供給に対する不安など，わが国における スポーツを取り巻く環境が厳しくなる中, 野球 による地方活性化, 学卒後のアスリートの受け 皿としてのコンテンツとしてのマイナーリーグ の役割は，今後大きくなっていくと思われる. 今後の日本野球の発展には, トップリーグの NPB が二軍の商品価值を高め, 独立リーグを 含めたマイナーリーグというスポーツビジネス として独り立ちさせる必要があるのだが, 展望 はいまだ描けていないのが現状である.

（注 1 ）独立リーグ球団の単年度収支において, BCリーグの石川球団は, 2008 年度の収支決算 において, 経常利益 0 とし, 均衡収支を達成し た.（BCリーグホームページ, http : //www.bc-l. $\mathrm{jp} /)$

（注 2 ）コロンバス球団は, 2007, 2008 年シーズン はワシントン・ナショナルズの $3 \mathrm{~A}$ チームとして 活動していた.

(注 3 ) コロンバス球団スタッフへのインタビュー (2009.8.9, コロンバス, ハンチントン・パーク 球場）より.

（注 4 ）コロンバス・クリッパーズの 2008 年シー ズンの 1 試合平均観客動員数は 7,795 人で全マイ
ナーリーグ球団中 12 位であった ${ }^{3)}$.

(注 5 ）注 3 に同じ.

(注 6 ) 注 3 に同じ.

(注 7 ) 2009 年シーズンの数字（マイナーリーグ ホームページ, http : //web.minorleaguebaseball. com). またこの数字は北米マイナーリーグ中 1 位であった。

(注 8 ) この球団, ケーンカウンティ・クガーズ は, マイナーリーグの成功例としてしばしば採 り上げられる. カーター\&ロベルも, シカゴか ら 1 時間圈内にフランチャイズを置くこの球団 が 1991 年の移転以来ほぼチケットを完売し続け ていることを述へ，その背景にメジャーリーグ 球団の入場料の高騰と, ケーンカウンティ球団 のファンサービスと地域密着の努力を挙げてい る4).

（注 $9 ）$ 長崎セインツオーナー (当時) ・地頭䄇哲 郎へのインタビュー（2009.9. 22, 平戸市赤坂球 場）より。

（注10）同上. 地頭蕚はまた,「チームを作るとこ ろまでは私がやったが, これを維持するのは地 域コミュニティの姿勢にかかっている」と述べ ていた。

（注11）長崎セインッのボランティアスタッフへの インタビュー（2009.9. 22, 平戸市赤坂球場）より. （注12）BCL 代表取締役・村山哲二へのインタ ビュー（2009. 10.18, 群馬県藤岡球場）より.

（注13）長崎セインツのボランティアスタッフ, ファンへのインタビュー（2009. 9. 22, 平戸市赤 坂球場）より.

（注14）長崎セインッ・根鈴雄次選手へのインタ ビュー（2009．9．22, 平戸市赤坂球場）より. 根鈴は高校野球の名門に入学するも家庭の事情 などから中退し, その後渡米し野球競技を続け た。一旦帰国し, 高校に復学のあと野球の名門 大学に入学し, 4 年間プレーした. 年齢の関係か らドラフトでの NPB 球団への入団は叶わなかっ たが, 再度渡米し, 2000 年, モントリオール。 エクスポズとマイナー契約を結び，3A クラスま で昇格した. 2001 年のエクスポズの春季一軍キャ ンプに参加したが, メジャー契約を勝ち取るこ とはできず，その後は米国の独立リーグ，メキ シコ, カナダのプロリーグ, オランダのセミ・ プロリーグでプレーし， 2007 年， BCリーグの 発足とともに同リーグの新潟球団に入団, 2009 
年からは IL の長崎球団でプレーした.

（注15）長崎セインツを支援していたサプライヤー の地元企業家は,「名前ばかりあっても NPBか ら落ちてきたベテランは不要である. 安月給覚 悟で夢を追いかけてがんばる若者の姿が見たく てこのチームを支援している.」と述べていた (2009.9. 20, 佐世保球場).

(注16) 注 14 に同じ.

（注 17）根鈴の他，NPB でもプレー経験のある前 田勝宏（調査当時 KIL 明石, 米国, 台湾, 中国, イタリアでプレー経験あり), 藤本博史 (調査当 時 KIL 明石, 米国, 台湾でプレ一経験あり), 長 坂秀樹（調査当時 IL 長崎, 北米でプレ一経験あ り）ら日本の独立リーグでプレーするベテラン 選手も同様の発言をしていた（前田勝宏へのイ ンタビュー, 2009. 5. 31, 明石球場, 藤本博史へ のインタビュー, 2009. 6. 21, 高砂市民球場, 長 坂秀樹へのインタビュー, 2009. 9. 22, 平戸市赤 坂球場).

（注18） BCL 代表取締役・村山哲二へのインタ ビュー（2010.7.25, 新潟県長岡市悠久山球場） より.

本稿執筆に際して実施したフィールドワーク の一部は, 2009 年度立命館大学大学院国際的 研究活動研究費による助成によるものである。

\section{参 考 文 献}

1) 不況, 挑むスポーツ界, 毎日新聞, 2009.4.21.

2) Johnson, Arthur T. ; Minor League Baseball and Local Economic Development, University of Illinois Press, 1993.

3 ) Baseball america Directory 2009, Baseball America, 2009, 94.

4 ）カーター, デビッド\&ロベル, ダレン, 原田 宗彦訳 ; アメリカ・スポーツビジネスに学ぶ 経営戦略, 大修館書店, 2006.

5 ) 杉本尚次; スタジアムは燃えている：日米野 球文化論, NHKブックス, 1992.

6) プロ野球球団誘致へ, 日刊スポーツ, 2009.9. 10.

7) Klein, Alan. M. ; Growing the Game: The Globalization of Major League Baseball, Yale University Press, 2006.

8 ）ブライマン, アラン, 森岡洋二訳; ディズニー 化する社会: 文化・消費・労働とグローバリゼー ション, 2008, pp.132-133.

9）ファン拡大に意欲, 読売新聞, 2007. 10. 25.

10）独立リーグ第 2 章(上)手をつなぎ市場拡大, 毎日新聞，2007. 11. 10.

11）穴吹工務店, 高松と広告契約せず, 四国新聞, 2009. 5. 28.

12）小野里真弓； BCリーグのマーケティングに関 する研究一群馬ダイヤモンドペガサスの観戦 者調査を事例として, 上武大学ビジネス情報 学部紀要 7 (2), pp.73-82, 2009. 